Article

\title{
Application of Global Reporting Initiative (GRI) Principles for Measuring Quality of Corporate Social Responsibility (CSR) Disclosure: Evidence from Pakistan
}

\author{
Hina Ismail ${ }^{1,+}$, Muhammad A. Saleem ${ }^{2, *,+} \oplus$, Sadaf Zahra ${ }^{1,+}\left(\mathbb{D}\right.$, Muhammad S. Tufail ${ }^{3, \dagger}$ and Rao Akmal Ali ${ }^{1}$ \\ 1 Department of Management, Faculty of Management Sciences, National University of Modern Languages, \\ Islamabad 40000, Pakistan; hina.ismail@numl.edu.pk (H.I.); sadaf.zahra@numl.edu.pk (S.Z.); \\ rakali@numl.edu.pk (R.A.A.) \\ 2 Asia Pacific College of Business and Law, Charles Darwin University, Ellengowan Dr, \\ Darwin, NT 0810, Australia; muhammad.saleem@cdu.edu.au \\ 3 Institute of Management Sciences, Bahauddin Zakariya University, Multan 60000, Pakistan; \\ sajidtufail@bzu.edu.pk \\ * Correspondence: muhammad.saleem@cdu.edu.au \\ + These authors contributed equally to this work.
}

Citation: Ismail, H.; Saleem, M.A.; Zahra, S.; Tufail, M.S.; Ali, R.A. Application of Global Reporting Initiative (GRI) Principles for Measuring Quality of Corporate Social Responsibility (CSR) Disclosure: Evidence from Pakistan. Sustainability 2021, 13, 11409. https:/ / doi.org/10.3390/su132011409

Academic Editor: Wen-Hsien Tsai

Received: 19 September 2021

Accepted: 8 October 2021

Published: 15 October 2021

Publisher's Note: MDPI stays neutral with regard to jurisdictional claims in published maps and institutional affiliations.

Copyright: (c) 2021 by the authors. Licensee MDPI, Basel, Switzerland. This article is an open access article distributed under the terms and conditions of the Creative Commons Attribution (CC BY) license (https:/ / creativecommons.org/licenses/by/ $4.0 /)$.

\begin{abstract}
CSR Reporting is an essential mechanism for ensuring the transparency and accountability of companies towards sustainability performance. To further promote that sustainable development agenda, CSR-related regulations and policies have emerged worldwide, including in Pakistan. Therefore this study assesses the quality of corporate social responsibility in annual reports issued by firms listed at the Pakistan Stock Exchange. This study has operationalized the Global Reporting Initiative (GRI) principles for examining the quality of CSR disclosures. The paper sample comprised 540 annual reports of 90 financial or non-financial companies from the years 2012 to 2017. Content analysis is performed to look for six quality principles and measures, i.e., balance, comparability, accuracy, clarity, reliability, and timeliness. Results suggested that most Pakistani firms provide precise and on-time information and put less emphasis on the balance of information and comparable information. Moreover, this study also highlighted that organizations should implement the GRI principle for disclosing qualitative CSR report.
\end{abstract}

Keywords: disclosure quality; CSR disclosure; global reporting initiative; developing countries; Pakistan

\section{Introduction}

CSR Reporting is an essential instrument for ensuring the transparent information of companies towards sustainable performance. Both shareholders and stakeholders demand financial as well as non-financial information for sustainable value creation. Stock exchanges worldwide have placed extra pressure on standard setters and listed companies to disclose CSR information [1]. Issuance of CSR reports is becoming a norm among various largest companies globally [2]. Despite an increasing trend toward the publication of CSR reports, the quality of these reports is a contentious issue [3]. CSR reporting has been criticized for its lack of relevance and credibility [4] and its failure to impact sustainable development [5]. The quality of the information is vital to enabling stakeholders to make sound and reasonable performance assessments and take appropriate actions.

In the recent decades academia has recognized the importance of transparent and responsible activities on environmental and social issues. A new paradigm of transparency can provide stakeholders the right to know the environmental and social information. Investors respond to disclosure of green investment more quickly when managers' decision regarding green investment reflect the value they place on the associated societal benefits [6]. 
In order to provide consistent information, various bodies have recommended a number of financial and non-financial disclosure standards in annual reports including Financial Accounting Standard Board (FASB), Global Reporting Initiatives (GRI), Directive 95/2014/EU and International Accounting Standards Board (IASB).

Voluntary disclosures provide incomparable and inconsistent information. The adoption of a standardized format such as triple bottom line reporting, Directive 95/2014/EU and GRI provided consistent and comparable information for firms and industry. Disclosure guidelines for nonfinancial information was introduced when companies focused on disclosing the information on environmental and social aspects in their annual reports [7]. For this purpose, various guidelines for measuring non-financial information were introduced such as triple bottom line, Directive 95/2014/EU [8] and Global Reporting Initiative (GRI) [9,10]. These guidelines mainly focus on management approaches (qualitative information) and performance indicators (quantitative information) [10]. According to Hammond and Miles [11], the companies who have followed GRI guidelines are more committed to disclose CSR information than those companies who do not follow it.

According to the guidelines, organizations are accountable to internal and external stakeholders and must follow the disclosure principles for introducing the transparent sustainability reports [2,9]. For example in Europe, states have introduced legal requirements about non-financial disclosure by introducing Directive 95/2014/EU [8]. Most of the companies use GRI sustainability reporting guidelines because it gives same coding structure for different industries and voluntary reporting frameworks that are useful for all type of companies [11,12].

Organizations communicate social and environmental activities through reporting practice and this reporting usually takes place annually in order to communicate CSR strategies effectively to their stakeholders [13]. A number of companies disclose CSR reports from the perspective of social, economic, and environmental performance [14]. Disclosure of CSR reporting is not only mandatory but relevant for institutions, green investors, and other agents.

The quality of CSR reporting has received relatively more little attention among researchers in both developed and developing countries [15]. Prior studies have applied various standards for measuring the quality of CSR disclosures. For example, Beretta and Bozzolan [1] used the qualitative characteristics of financial reporting information (understandability, relevance, reliability, and comparability) to examine social disclosures' quality. Anis, Fraser [16] follow the Operating and Financial Review best practice (OFR) framework as a base for developing their measure of disclosure quality and found that the characteristics of disclosure quality must have some attributes such as forward-looking orientation, verifiability, relevance, supplementary and complementary financial statements, comprehensiveness, balance and neutrality and comparability. Applying the qualitative characteristics of financial information to social disclosures was considered limited and less relevant for social disclosures by some researchers who call for a separate evaluation framework to assess the quality of social discourse [17].

This study aims to examine the quality of the information through the principles for defining reporting quality by Global Reporting Initiative (GRI). GRI is recognized as a leader in the international standardization of non-financial reporting [2]. GRI provides a rigorous framework for CSR reporting. The GRI Reporting Principles are divided into two groups: principles for defining report content and defining report quality. The directions for determining report content describe the process to be applied to identify the report's range by considering its activities, impacts, and stakeholders' substantive expectations and interests. The principles for defining report quality guide choices on ensuring the quality of the information in the sustainability report, including its proper presentation.

The empirical content of this paper is from Pakistan, where CSR reporting is taking roots. This research emphasis on GRI sustainability reporting guidelines related to management approaches (qualitative information) and performance indicators [10]. Financial disclosure of CSR is mandatory under SECP General Order 2009, whereas for other pro- 
cesses related to CSR Reporting, SECP issued Voluntary Guidelines in 2012. The guidelines also mentioned that companies should follow relevant CSR reporting frameworks for various functions associated with CSR Reporting. Therefore, we examine the quality of CSR Reporting in Pakistan from 2012-2017 to see the impact of guidelines. This paper is motivated by the desire to improve the quality of CSR reporting by assessing its current state so that practitioners and policymakers are well informed to enhance current practice. This paper contributes to the literature on CSR reporting in developing countries in general and the quality of CSR disclosures. Currently, disclosure study in developing countries, particularly in Pakistan, is based on the quantity of CSR disclosure [18]. Limited studies focus on the quality of CSR disclosure [15]. Although prior studies have examined the quality of CSR reporting, none has operationalized the GRI reporting principles for defining quality. The rest of the paper is structured as follows.

\section{Literature Review}

CSR practice reporting in annual reports is becoming a global trend that is not limited to developed markets, but has started to penetrate into emerging markets [19]. The notion of corporate social responsibility (hereafter CSR) has become a standard element for national and international organizations. The majority of the studies highlight CSR discussion and CSR reporting in Australia, Western Europe and the USA [19,20] The ratio of conducted studies related to CSR disclosers in the USA is higher than in other parts of developed countries. By contrast, CSR discussion in developing countries have received less attention [19].

Existing studies observed that regulations focused on the quantity of information disclosed annually but not on the quality of the reports [21]. Studies have also detected that when disclosures are prepared according to the reporting standard (such as the GRI standards) and legal provision (such as Directive 95/2014/EU), the overall quality of their content could be different [22].

The quality of CSR disclosure is an important issue both for companies and their stakeholders. Quality of CSR disclosures allow stakeholders to "make sound and reasonable assessments of performance and take appropriate action" (GRI, 2006, p. 13). Companies who provide the quality of CSR information can win the trust and confidence of stakeholders [23]. However, measuring disclosure quality remains a highly contentious issue, and various definitions and measurements exist in literature $[1,24,25]$. There is no universal set of principles that constitute the quality of social disclosure, and there is a great deal of practice variation in evaluating the quality of social exposure.

Despite this, there is a consensus that CSR reports will be useful if certain qualitative characteristics are present [26]. In academic research, the concept of quality has been conceived and applied differently by different researchers. Existing literature has discussed different characteristics for providing qualitative information in CSR disclosure [2,17,22,27-30]. This section mainly reviews existing research that measures the quality of social disclosure and some of the frameworks/standards used for measuring reporting quality.

Habek and Wolniak [31] explained two qualitative characteristics of disclosures: relevance and credibility. Leitoniene and Sapkauskiene [32] described three qualitative aspects of social disclosures: relevance, reliability, and comparability. Similarly, the researcher Michelon [2], explain disclosure quality through three dimensions: the content of the information disclosed (what and how much is disclosed), the type of information used to describe and discuss CSR issues (how it is disclosed), and the managerial orientation (the corporate approach to CSR). Brammer and Pavelin [33] evaluated the quality of voluntary environmental disclosure through quality indicators. Raar [34] assesses the quality of social and environmental disclosure in companies with monetary, non-monetary, and qualitative discussion. Among other things that characterize the quality of social disclosure include a range of issues disclosed, nature of disclosure, frequency of reporting, style of disclosure, the scope of the report, themes of disclosure, period of disclosing information, and coverage of disclosure [11]. 
Overall, two general approaches for measuring the quality of CSR disclosure can be identified in the existing literature. One approach is to identify a range of criteria by conducting a literature review [35], while another approach measure quality through criteria from reporting (financial and non-financial) standards and guidelines [36]. While some studies rate information based on whether it is disclosed or not disclosed [37], others involve a more sophisticated rating of the information reported on a scale depending on how data adheres to reporting requirements [38]. For instance, Cormier, Magnan, and Van Velthoven [39] measured the quality of the information in CSR disclosure based on the nature of qualitative, quantitative, and monetary disclosure information regarding the theme. On the other hand, van Staden and Hooks [40] used a seven-point [34] and fivepoint ranking scale [40] to measure the quality of environmental disclosure. In terms of the second approach, prior studies have mainly applied financial reporting standards on CSR reporting (see. e.g., Beretta and Bozzolan [1,41]. This has been considered a major limitation, since using the qualitative characteristics of financial information to make social disclosures was considered less relevant and less justified by some researchers, who call for a separate evaluation framework for assessing the quality of social discourse [17,42]. One such framework that has received less attention in the existing literature is the Global Reporting Initiative, which defined principles for determining the reporting content and quality.

According to the Global Reporting Initiative (GRI), principles for measuring reporting quality include balance, comparability, accuracy, timeliness, clarity, and reliability. CSR reports should provide balanced information for making them decision-useful for stakeholders. According to GRI (2006) (p. 13), "the report should reflect positive and negative aspects of the organization's performance to enable a reasoned assessment of overall performance". Existing research found that companies disclose more positive events over the so-called adverse events [22,43] and criticizes companies for not providing balanced information [44]. Comparability of CSR information is another principle for providing quality CSR information that allows users or stakeholders to assess the performance of organizations [45]. According to GRI (2006) p. 14, "reported information should be presented in a manner that enables stakeholders to analyze changes in the organization's performance over time and could support analysis relative to other organizations". Measurement of a firm's performance over time and comparability with the other organizations in the same industry is the essential characteristic of quality disclosure.

Organizations must describe an accurate technique for calculation and data measurement. Qualitative information in the report should be validated (GRI, 2016). Accuracy of information is essential for the quality of CSR disclosure, $2[29,43]$. GRI $(2016$, p. 13) explain accuracy as "the reported information should be sufficiently accurate and detailed for stakeholders to assess the reporting organization's performance". Literature supports the conclusion that financial analysts, stakeholders, and investors should examine the quality of information through these principles [42,46,47]. Managers who make decisions regarding green investment use these principles to obtain quality information [6]. Timeliness is the fourth principle of quality disclosure of CSR, though it is not taken seriously in the literature of sustainability disclosure [48]. Timeliness is defined in the disclosure principle of GRI $(2016$, p. 16) as the disclosure of CSR information according to a regular schedule; the information should be available in time for stakeholders. This principle also indicates that recent information should be communicated helpfully to help stakeholders in decision making [29].

Clarity is the fifth principle of CSR disclosure quality. Under this principle, disclosure of CSR information must be understandable, usable, and accessible by all stakeholders to find specific information without great effort (GRI, 2016). In previous literature, researchers argued that lack of clarity, such as unnecessary and excessive information, acronyms, jargon or confusing language, is found in CSR disclosure, and misguides the stakeholders [22,49]. In addition to this, GRI recommends using maps, graphics, links, indices, tables, and other content so that stakeholders' understanding will not be limited. Finally, the information in CSR disclosure should be reliable. According to GRI (2016, p. 16), processes used to 
prepare a report should be gathered, recorded, compiled, analyzed, and disclosed in a way that could be subject to examination.

\section{Materials and Methods}

This research developed a comprehensive set of measures to operationalize the GRI principles for defining reporting quality. The empirical content in this paper is based on the annual CSR reports published by the 90 companies listed on the Pakistan stock exchange from 2012-2017. Classification of sample companies are shown in Table 1.

Table 1. Classification of Sampled companies.

\begin{tabular}{|c|c|c|c|}
\hline No. & Industry Category & Aggregate Sample & Sample Percentage \\
\hline \multicolumn{4}{|c|}{ Non-financial Firms } \\
\hline \multirow[t]{4}{*}{1.} & Textiles & & \\
\hline & (i) Spinning, weaving, finishing of textiles & 5 & 6 \\
\hline & (ii) Made-up textile articles & 1 & 1 \\
\hline & (iii) Other textiles & 2 & 2 \\
\hline 2. & Sugar & 2 & 2 \\
\hline 3. & Food & 7 & 8 \\
\hline 4. & Chemicals, chemical products, and pharmaceuticals & 10 & 11 \\
\hline 5. & Manufacturing & 5 & 6 \\
\hline 6. & Mineral products & 1 & 1 \\
\hline 7. & Cement & 9 & 10 \\
\hline 8. & Motor vehicles, trailers, and auto parts & 4 & 4 \\
\hline 9. & Fuel and energy & 5 & 6 \\
\hline 10. & Information, communication and transport Services & 4 & 4 \\
\hline 11. & Coke and refined petroleum products & 7 & 8 \\
\hline 12. & Paper, paperboard, and products & 2 & 2 \\
\hline 13. & Electrical machinery and apparatus & 1 & 1 \\
\hline 14. & Other services activities and miscellaneous & 7 & 8 \\
\hline \multicolumn{4}{|c|}{ Financial Firms } \\
\hline 15. & Banks & 11 & 12 \\
\hline 16. & Leasing companies & 1 & 1 \\
\hline 17. & Mutual fund companies & 1 & 1 \\
\hline \multirow[t]{3}{*}{18.} & Insurance companies & & \\
\hline & (i) Life insurance companies & 1 & 1 \\
\hline & (ii) Non-life insurance companies & 3 & 3 \\
\hline 19. & Investment company & 1 & 1 \\
\hline
\end{tabular}

This study performed content analysis to look for instances that can substantiate quality principles and measures. According to the GRI principles, the information provided in annual reports should have qualitative characteristics (i.e., balance, comparability, accuracy, clarity, reliability, and timeliness). This paper has combined the GRI principles for reporting quality and measures used by existing studies that correspond with GRI principles to develop a comprehensive framework for measuring the quality of CSR disclosure $[1,24,25]$.

Appendix A provides an overview of the ten quality indicators used to operationalize six principles for measuring reporting quality as mentioned in the GRI framework. This paper synthesizes the efforts of previous researchers in improving disclosure quality and enhances empirical disclosure studies measuring quality. Operationalization of six qualitative characteristics of reporting CSR information is based on ten indicators, out of which two are related to balance; two are related to comparability; one relates to accuracy; two to timeliness; one to clarity and two to reliability. For each measure, a scale has been developed based on the GRI guidelines and existing studies. For instance, for measuring the balance of CSR information, two indicators (B1 and B2) were measured on a scale of 1-5. There are two indicators (R1 and R2) for measuring comparability, measured on a scale of 1-5. Accuracy consists of one indicator (A1) that is calculated using a fivepoint rating scale. Timeliness consists of two indicators (T1 and T2) that were measured 
using dichotomous variables. Clarity consists of one indicator (C1) measured through an understand-ability index as mentioned in Appendix A. Reliability consists of two indicators (R1 and R2) measured using a dichotomous variable. Hence, this study used 36 items for operationalizing the CSR disclosure quality. Measurement of dimension and indicators of quality of CSR disclosure mentioned in Table 2.

Table 2. Measurement of dimensions of quality of CSR disclosure and its indicators.

\begin{tabular}{cccc}
\hline Quality Principle & Indicators & Scale & Total Score \\
\hline \multirow{2}{*}{ Balance (B) } & B1 & $1-5$ & 5 \\
& B2 & $1-5$ & 5 \\
\hline \multirow{2}{*}{ Comparability (C) } & C1 & $1-5$ & 5 \\
& C2 & $1-5$ & 5 \\
\hline Accuracy (A) & A1 & $1-6$ & 6 \\
\hline \multirow{2}{*}{ Timeliness (T) } & T1 & & 2 \\
\hline Clarity (C) & T2 & & 2 \\
\hline \multirow{2}{*}{ Reliability (R) } & C1 & & 2 \\
\hline & R1 & & 2 \\
\hline
\end{tabular}

\section{Findings}

\subsection{Balanced CSR Disclosure}

Tables 3 and 4 give the result on companies disclosed balance information in CSR reporting. Table 3 shows the balance of CSR information in terms of the balance of positives and negative events. The majority of the companies disclosed positive or favorable events in their CSR reports (2017: 72 companies, 80\%, 2016: 72 companies, 80\%, 2015: 72 companies, 80\%, 2014: 71 companies, 78.9\%; 2013: 66 companies, 73.1\%; 2012: 64 companies, 71.1\%) and only one company $(1.1 \%)$ disclosed negative or unfavorable events from the year 2012-2017. Of further concern some sampled companies (2017: 14 companies, 15.6\%, 2016: 14 companies, 15.6\%, 2015: 14 companies, 15.6\%, 2014: 16 companies, 17.8\%; 2013: 20 companies, 22.2\%; 2012: 22 companies, 24.4\%) disclosed neither positive nor negative events in CSR report. During the analysis, it was noticed that firms reported no "balance of events" in their CSR reports, and the trend of disclosing positive events has increased from 2012 to 2017.

Table 3. Overview of positive and negative events disclosure 2012-2017.

\begin{tabular}{|c|c|c|c|c|c|c|c|c|c|c|c|c|c|c|}
\hline \multirow[t]{2}{*}{ Years } & \multicolumn{2}{|c|}{$\begin{array}{l}\text { No Events } \\
\text { (+ve/-ve) }\end{array}$} & \multicolumn{2}{|c|}{-ve Events } & \multicolumn{2}{|c|}{$\begin{array}{c}\text { +ve } \\
\text { Events }\end{array}$} & \multicolumn{2}{|c|}{$\begin{array}{c}\text { Balance of } \\
\text { Events } \\
(+v e /-v e)\end{array}$} & \multicolumn{2}{|c|}{$\begin{array}{c}\text { Impact of } \\
\text { Events } \\
\text { (+ve/-ve) }\end{array}$} & \multirow[t]{2}{*}{ Mean } & \multirow[t]{2}{*}{$\begin{array}{l}\text { Std. } \\
\text { Dev. }\end{array}$} & \multirow[t]{2}{*}{ Mini } & \multirow[t]{2}{*}{ Maxi. } \\
\hline & $N$ & $\%$ & $N$ & $\%$ & $N$ & $\%$ & $N$ & $\%$ & $N$ & $\%$ & & & & \\
\hline 2012 & 22 & 24.4 & 1 & 1.1 & 64 & 71.1 & 0 & 0 & 3 & 3.3 & 0.513 & 0.194 & 0.2 & 1 \\
\hline 2013 & 20 & 22.2 & 1 & 1.1 & 66 & 73.1 & 0 & 0 & 3 & 3.3 & 0.522 & 0.189 & 0.2 & 1 \\
\hline 2014 & 16 & 17.8 & 1 & 1.1 & 71 & 78.9 & 0 & 0 & 2 & 2.2 & 0.536 & 0.170 & 0.2 & 1 \\
\hline 2015 & 14 & 15.6 & 1 & 1.1 & 72 & 80.0 & 0 & 0 & 3 & 3.3 & 0.549 & 0.168 & 0.2 & 1 \\
\hline 2016 & 14 & 15.6 & 1 & 1.1 & 72 & 80.0 & 0 & 0 & 3 & 3.3 & 0.549 & 0.168 & 0.2 & 1 \\
\hline 2017 & 14 & 15.6 & 1 & 1.1 & 72 & 80.0 & 0 & 0 & 3 & 3.3 & 0.549 & 0.168 & 0.2 & 1 \\
\hline
\end{tabular}


Table 4. Overview of performance trends of positive and negative events in year to year basis.

\begin{tabular}{ccccccccccccc}
\hline Years & $\begin{array}{c}\text { No } \\
\text { Performance } \\
\text { (+ve/-ve) }\end{array}$ & \multicolumn{2}{c}{$\begin{array}{c}\text {-ve } \\
\text { Performance }\end{array}$} & $\begin{array}{c}\text { +ve } \\
\text { Performance }\end{array}$ & $\begin{array}{c}\text { Balance of } \\
\text { Performance } \\
\text { +ve/-ve) }\end{array}$ & $\begin{array}{c}\text { Impact of } \\
\text { Performance } \\
\text { (+ve/-ve) }\end{array}$ & Mean & $\begin{array}{c}\text { Std. } \\
\text { Dev. }\end{array}$ & Mini \\
Maxi.
\end{tabular}

Note: Each year's sample contains 90 companies.

Table 4 shows the sampled companies that allow users to see positive and negative trends in performance on a year to year basis. Many sampled companies disclosed "no positive or negative performance" separately and year to a yearly basis in their CSR reports (85 companies, $94.4 \%$ ) and only five companies (5.5\%) disclosed "positive performance" separately and year to year basis in 2017.

Similar to 2017, a large number of sampled companies not focused on "positive or negative performance" separately and year to year basis (2016: 87 companies, 96.7\%, 2015: 87 companies, 96.7\%, 2014: 87 companies, 96.7\%; 2013: 86 companies, 95.6\%; 2012: 83 companies, $92.2 \%$ ) and a small number of sampled companies disclosed "positive performance" separately and year to year basis (2016: 3 companies, 96.7\%, 2015: 3 companies, $96.7 \%$, 2014: 3 companies, 96.7\%; 2013: 4 companies, 95.6\%; 2012: 7 companies, 92.2\%). During the analysis, it was noticed that firms are reporting no "balance and impact of performance" and even no "negative performance" in their CSR reports.

\subsection{Comparability}

Tables 5 and 6 show results on comparable information disclosed in annual reports. Similar information with other organizations disclosed either in one paragraph, two paragraphs, or more than two paragraphs. None of the listed companies on the Pakistan Stock Exchange have announced a single section comparing CSR information with other organizations (90 companies, 100\%).

Table 5. Overview of CSR information comparability with other organization.

\begin{tabular}{|c|c|c|c|c|c|c|c|c|c|c|c|c|c|c|}
\hline \multirow[t]{2}{*}{ Years } & \multicolumn{2}{|c|}{$\begin{array}{c}\text { No } \\
\text { Comparability } \\
\text { (No Paragraph) }\end{array}$} & \multicolumn{2}{|c|}{$\begin{array}{c}\text { Limited } \\
\text { Comparability } \\
\text { (One } \\
\text { Paragraph) }\end{array}$} & \multicolumn{2}{|c|}{$\begin{array}{c}\text { Moderate } \\
\text { Comparability } \\
\text { (Two } \\
\text { Paragraph) }\end{array}$} & \multicolumn{2}{|c|}{$\begin{array}{c}\text { Very Much } \\
\text { Comparability } \\
\text { (Two Paragraph } \\
\text { with Numbering) }\end{array}$} & \multicolumn{2}{|c|}{$\begin{array}{c}\text { Very Extensive } \\
\text { Comparability } \\
\text { (More Than } \\
\text { Two Paragraph) }\end{array}$} & \multirow[t]{2}{*}{ Mean } & \multirow[t]{2}{*}{$\begin{array}{l}\text { Std. } \\
\text { Dev. }\end{array}$} & \multirow[t]{2}{*}{ Mini } & \multirow[t]{2}{*}{ Maxi. } \\
\hline & $N$ & $\%$ & $N$ & $\%$ & $N$ & $\%$ & $N$ & $\%$ & $N$ & $\%$ & & & & \\
\hline 2012 & 90 & 100 & 0 & 0 & 0 & 0 & 0 & 0 & 0 & 0 & 0.2 & 3.8 & 0.2 & 0.2 \\
\hline 2013 & 90 & 100 & 0 & 0 & 0 & 0 & 0 & 0 & 0 & 0 & 0.2 & 3.6 & 0.2 & 0.2 \\
\hline 2014 & 90 & 100 & 0 & 0 & 0 & 0 & 0 & 0 & 0 & 0 & 0.2 & 3.8 & 0.2 & 0.2 \\
\hline 2015 & 90 & 100 & 0 & 0 & 0 & 0 & 0 & 0 & 0 & 0 & 0.2 & 3.6 & 0.2 & 0.2 \\
\hline 2016 & 90 & 100 & 0 & 0 & 0 & 0 & 0 & 0 & 0 & 0 & 0.2 & 3.6 & 0.2 & 0.2 \\
\hline 2017 & 90 & 100 & 0 & 0 & 0 & 0 & 0 & 0 & 0 & 0 & 0.2 & 3.6 & 0.2 & 0.2 \\
\hline
\end{tabular}

Note: Each year's sample contains 90 companies.

Table 6 shows that sampled companies highlight the yearly basis comparison of CSR information. Results reveal that most companies have not compared CSR information of previous years with other organizations (87 companies, 96.7\%) in their CSR disclosure of 2017. Only one company $(1.11 \%)$ shows limited, one company $(1.11 \%)$ shows moderate, and one company $(1.11 \%)$ shows very extensive comparability of CSR information. Similar to 2017, a large number of sampled companies were not focused on the comparability of CSR information with other organizations on a year-to-year basis (2016: 87 companies, 
96.7\%; 2015: 87 companies, 96.7\%; 2014: 87 companies, 96.7\%; 2013: 87 companies, 96.7\%; 2012: 89 companies, $98.9 \%$ ). In contrast, only one company (1.11\%) disclosed limited, moderate, and very extensive comparability of CSR information. During the analysis, it was noticed that no company compared three years of CSR information in their CSR reports.

Table 6. Overview of CSR information comparability with other organizations on a year-to-year basis.

\begin{tabular}{|c|c|c|c|c|c|c|c|c|c|c|c|c|c|c|}
\hline \multirow[t]{2}{*}{ Years } & \multicolumn{2}{|c|}{$\begin{array}{c}\text { No } \\
\text { Comparability } \\
\text { (No Prior Year) }\end{array}$} & \multicolumn{2}{|c|}{$\begin{array}{c}\text { Limited } \\
\text { Comparability } \\
\text { (One Year) }\end{array}$} & \multicolumn{2}{|c|}{$\begin{array}{c}\text { Moderate } \\
\text { Comparability } \\
\text { (Two Years) }\end{array}$} & \multicolumn{2}{|c|}{$\begin{array}{l}\text { Very Much } \\
\text { Comparability } \\
\text { (Three Years) }\end{array}$} & \multicolumn{2}{|c|}{$\begin{array}{c}\text { Very Extensive } \\
\text { Comparability } \\
\text { (More Than } \\
3 \text { Years) }\end{array}$} & \multirow[t]{2}{*}{ Mean } & \multirow[t]{2}{*}{$\begin{array}{l}\text { Std. } \\
\text { Dev. }\end{array}$} & \multirow[t]{2}{*}{ Mini } & \multirow[t]{2}{*}{ Maxi. } \\
\hline & $N$ & $\%$ & $N$ & $\%$ & $N$ & $\%$ & $N$ & $\%$ & $N$ & $\%$ & & & & \\
\hline 2012 & 89 & 98.9 & 0 & 0 & 0 & 0 & 0 & 0 & 1 & 1.1 & 0.21 & 0.08 & 0.2 & 1 \\
\hline 2013 & 87 & 96.7 & 1 & 1.1 & 0 & 0 & 0 & 0 & 2 & 2.2 & 0.22 & 0.12 & 0.2 & 1 \\
\hline 2014 & 87 & 96.7 & 1 & 1.1 & 1 & 1.1 & 0 & 0 & 1 & 1.1 & 0.22 & 0.01 & 0.2 & 1 \\
\hline 2015 & 87 & 96.7 & 1 & 1.1 & 1 & 1.1 & 0 & 0 & 1 & 1.1 & 0.22 & 0.10 & 0.2 & 1 \\
\hline 2016 & 87 & 96.7 & 1 & 1.1 & 1 & 1.1 & 0 & 0 & 1 & 1.1 & 0.22 & 0.10 & 0.2 & 1 \\
\hline 2017 & 87 & 96.7 & 1 & 1.1 & 1 & 1.1 & 0 & 0 & 1 & 1.1 & 0.22 & 0.10 & 0.2 & 1 \\
\hline
\end{tabular}

Note: Each year's sample contains 90 companies.

\subsection{Accuracy}

Table 7 shows the companies that disclosed accurate CSR information for stakeholders to assess the organization's performance. Methods and data used to evaluate the performance in preparation for the report are clear. Sampled companies accurately disclosed the quality of CSR information (51 companies, 56.7\%), and a small number of companies disclosed qualitative information with the same quantitative information (17 companies, 18.7\%) and some did not even disclose any CSR activities accurately (12 companies, 13.3\%) in 2017.

Table 7. Overview of accurately disclosed CSR activities.

\begin{tabular}{|c|c|c|c|c|c|c|c|c|c|c|c|c|c|c|c|c|}
\hline \multirow[t]{2}{*}{ Years } & \multicolumn{2}{|c|}{$\begin{array}{c}\text { No } \\
\text { Accurate } \\
\text { Information }\end{array}$} & \multicolumn{2}{|c|}{$\begin{array}{l}\text { Qualitative } \\
\text { Information }\end{array}$} & \multicolumn{2}{|c|}{$\begin{array}{c}\text { Qualitative } \\
\text { and } \\
\text { Quantitative }\end{array}$} & \multicolumn{2}{|c|}{\begin{tabular}{l}
\multicolumn{1}{c}{ More } \\
Quantitative \\
Information
\end{tabular}} & \multicolumn{2}{|c|}{$\begin{array}{c}\text { Adequately } \\
\text { Describe Data } \\
\text { Measurement } \\
\text { Technique }\end{array}$} & \multicolumn{2}{|c|}{$\begin{array}{l}\text { Estimation } \\
\text { and } \\
\text { Assumption }\end{array}$} & \multirow[t]{2}{*}{ Mean } & \multirow[t]{2}{*}{$\begin{array}{l}\text { Std. } \\
\text { Dev. }\end{array}$} & \multirow[t]{2}{*}{ Mini } & \multirow[t]{2}{*}{ Maxi. } \\
\hline & $N$ & $\%$ & $N$ & $\%$ & $N$ & $\%$ & $N$ & $\%$ & $N$ & $\%$ & $N$ & $\%$ & & & & \\
\hline 2012 & 21 & 23.3 & 53 & 58.9 & 10 & 11.1 & 3 & 3.3 & 1 & 1.1 & 2 & 2.2 & 0.21 & 0.19 & 0 & 1 \\
\hline 2013 & 18 & 20 & 51 & 56.7 & 14 & 15.6 & 4 & 4.4 & 1 & 1.1 & 2 & 2.2 & 0.23 & 0.20 & 0 & 1 \\
\hline 2014 & 13 & 14.4 & 54 & 60.0 & 15 & 16.7 & 5 & 5.6 & 1 & 1.1 & 2 & 2.2 & 0.25 & 0.19 & 0 & 1 \\
\hline 2015 & 12 & 13.3 & 51 & 56.7 & 17 & 18.9 & 7 & 7.8 & 1 & 1.1 & 2 & 2.2 & 0.27 & 0.10 & 0 & 1 \\
\hline 2016 & 12 & 13.3 & 51 & 56.7 & 17 & 18.9 & 7 & 7.8 & 1 & 1.1 & 2 & 2.2 & 0.27 & 0.10 & 0 & 1 \\
\hline 2017 & 12 & 13.3 & 51 & 56.7 & 17 & 18.9 & 7 & 7.8 & 1 & 1.1 & 2 & 2.2 & 0.27 & 0.10 & 0 & 1 \\
\hline
\end{tabular}

Note: Each year's sample contains 90 companies.

Similar to 2017, a large number of sampled companies accurately disclosed qualitative information of CSR activities in their CSR reports (2016: 54 companies, 2015: 54 companies 2014: 54 companies, 60\%; 2013: 51 companies, 56.7\%; 2012: 53 companies, 58.9\%) and a small number of companies disclosed qualitative information with the same quantitative information (2016: 15 companies, 16.7\%, 2015: 15 companies, 16.7\%, 2014: 15 companies, 16.7\%; 2013: 14 companies, 15.6\%; 2012: 10 companies, 11.1\%). During the analysis, it was noticed that only two sampled companies (2.2\%) accurately disclosed estimation and underlying assumptions, whereas one company adequately described accuracy measurement technique and basic calculation for accuracy from the years 2012 to 2017. 


\subsection{Timeliness}

Tables 8 and 9 provide a comprehensive picture of the GRI timeliness and its indicators. Table 8 shows that the sampled companies disclosed regular annual reports that clearly indicated the period and were updated accordingly. A large number of sampled companies regularly disclosed financial information in their annual reports, which clearly show the specific period and were updated accordingly (79 companies, $87.8 \%$ ) and a small number of companies did not clearly indicate the particular period and were not updated accordingly (12 companies, 13.3\%) in 2017.

Table 8. Overview of regular discloser of CSR information.

\begin{tabular}{ccccccccc}
\hline \multirow{2}{*}{ Years } & \multicolumn{2}{c}{$\begin{array}{c}\text { No } \\
\text { Time Specified }\end{array}$} & \multicolumn{2}{c}{ Time Specified } & Mean & $\begin{array}{c}\text { Std. } \\
\text { Dev. }\end{array}$ & Mini & Maxi. \\
& $\boldsymbol{N}$ & $\mathbf{\%}$ & $\boldsymbol{N}$ & $\mathbf{\%}$ & & & & \\
\hline 2012 & 12 & 13.3 & 78 & 86.7 & 0.93 & 0.17 & 0.5 & 1 \\
2013 & 12 & 13.3 & 78 & 86.7 & 0.93 & 0.17 & 0.5 & 1 \\
2014 & 12 & 13.3 & 78 & 86.7 & 0.93 & 0.17 & 0.5 & 1 \\
2015 & 11 & 12.2 & 79 & 87.8 & 0.94 & 0.16 & 0.5 & 1 \\
2016 & 11 & 12.2 & 79 & 87.8 & 0.94 & 0.16 & 0.5 & 1 \\
2017 & 11 & 12.2 & 79 & 87.8 & 0.94 & 0.16 & 0.5 & 1 \\
\hline
\end{tabular}

Note: Each year's sample contains 90 companies.

Table 9. Overview of consistent reporting schedule.

\begin{tabular}{ccccccccc}
\hline Years & \multicolumn{2}{c}{ Yes } & \multicolumn{2}{c}{ No } & Mean & Std. Dev. & Mini & Maxi. \\
\hline & $\boldsymbol{N}$ & $\mathbf{\%}$ & $\boldsymbol{N}$ & $\mathbf{\%}$ & & & & \\
\hline 2012 & 84 & 93.3 & 6 & 6.7 & 0.53 & 0.13 & 0.5 & 1 \\
2013 & 85 & 94.4 & 5 & 5.6 & 0.53 & 0.12 & 0.5 & 1 \\
2014 & 83 & 92.2 & 7 & 7.8 & 0.53 & 0.13 & 0.5 & 1 \\
2015 & 83 & 92.2 & 7 & 7.8 & 0.54 & 0.13 & 0.5 & 1 \\
2016 & 83 & 92.2 & 7 & 7.8 & 0.54 & 0.13 & 0.5 & 1 \\
2017 & 83 & 92.2 & 7 & 7.8 & 0.54 & 0.13 & 0.5 & 1 \\
\hline
\end{tabular}

Similar to 2017, a large number of sampled companies regularly disclosed financial information in their annual reports, clearly indicating the specific period and updating accordingly (2016; 2015; 2014; 2013; 2012: 78 companies, 86.7\%), whereas a small number of companies did not indicate the specific period and were not updated accordingly (2016; 2015; 2014; 2013; 2012: 12 companies, 13.3\%).

Table 9 shows that the sampled companies highlight consistent reporting schedules in annual reports. A large number of sampled companies did not consistently disclose reporting schedules (83 companies, $92.2 \%$ ), and a small number of companies had not been consistently disclosing reporting schedules (7 companies, 7.8\%) in 2017. Similar to 2017, a large number of sampled companies consistently disclosed reporting schedule (2016: 83 companies, 92.2\%, 2015: 83 companies, 92.2\%, 2014: 83 companies, 92.2\%; 2013: 85 companies, 94.4\%; 2012: 84 companies, $93.3 \%$ ) and small number of companies did not consistently disclose reporting schedule (2016: 7 companies, 7.8\%, 2015: 7 companies, 7.8\%, 2014: 7 companies, 7.8\%; 2013: 5 companies, 5.6\%; 2012: 6 companies, $6.7 \%$ ).

\subsection{Clarity}

Table 10 provides a comprehensive picture of the GRI clarity. The result shows that sampled companies disclose CSR information easily and understandably to various stakeholders. During the analysis, it was noticed that 51 companies $(56.7 \%)$ announced clear information regarding CSR issues with graphs, maps, table of contents, list of abbreviations, pictures, tables and in multiple languages. In contrast, clear communication is absent in 39 companies (43.3\%) for the year 2017. 
Table 10. Overview of clear CSR information.

\begin{tabular}{ccccccccc}
\hline Years & \multicolumn{2}{c}{ Present } & \multicolumn{2}{c}{ Absent } & Mean & Std. Dev. & Mini & Maxi. \\
\hline & $\boldsymbol{N}$ & $\boldsymbol{\%}$ & $\boldsymbol{N}$ & $\boldsymbol{\%}$ & & & & \\
\hline 2012 & 41 & 45.6 & 49 & 54.4 & 0.74 & 0.28 & 0 & 1 \\
2013 & 47 & 52.2 & 43 & 47.8 & 0.74 & 0.25 & 0.5 & 1 \\
2014 & 51 & 56.7 & 39 & 43.3 & 0.71 & 0.26 & 0 & 1 \\
2015 & 51 & 56.7 & 39 & 43.3 & 0.71 & 0.26 & 0 & 1 \\
2016 & 51 & 56.7 & 39 & 43.3 & 0.71 & 0.26 & 0 & 1 \\
2017 & 51 & 56.7 & 39 & 43.3 & 0.71 & 0.26 & 0 & 1 \\
\hline Note: Each year's sample contains 90 companies.
\end{tabular}

Note: Each year's sample contains 90 companies.

Similar to 2017, clear CSR information is present in the shape of graphs, maps, table of contents, list of abbreviations, pictures, tables, and schedules in multiple languages in CSR reports for a large number of companies (2016: 51 companies, 56.7\%; 2015: 51 companies, 56.7\%; 2014: 51 companies, 56.7\%; 2013: 47 companies, 52.2\%; 2012: 41 companies, 45.6\%). Clear information is absent in a small number of companies (2016: 39 companies, $43.3 \%$, 2015: 39 companies, 43.3\%,2014: 39 companies, 43.3\%; 2013: 39 companies, 43.3\%; 2012: 49 companies, $54.4 \%)$.

\subsection{Reliability}

Tables 11 and 12 show that reliable information was disclosed by companies. Table 11 shows the sampled companies highlight an assurance statement, which includes the assurance of reporting data. Assurance providers can assure the reliability of disclosure. This assurance provider (external validation) can be an accountant from an engineering and small consultancy firm.

Table 11. Overview of assurance of reporting data.

\begin{tabular}{|c|c|c|c|c|c|c|c|c|}
\hline \multirow[t]{2}{*}{ Years } & \multicolumn{2}{|c|}{$\begin{array}{c}\text { No External } \\
\text { Assurance }\end{array}$} & \multicolumn{2}{|c|}{$\begin{array}{c}\text { External } \\
\text { Assurance }\end{array}$} & \multirow[t]{2}{*}{ Mean } & \multirow[t]{2}{*}{$\begin{array}{l}\text { Std. } \\
\text { Dev. }\end{array}$} & \multirow[t]{2}{*}{ Mini } & \multirow[t]{2}{*}{ Maxi. } \\
\hline & $N$ & $\%$ & $N$ & $\%$ & & & & \\
\hline 2012 & 4 & 4.4 & 86 & 95.6 & 0.98 & 0.10 & 0.5 & 1 \\
\hline 2013 & 1 & 1.1 & 89 & 98.9 & 0.98 & 0.10 & 0.5 & 1 \\
\hline 2014 & 1 & 1.1 & 89 & 98.9 & 0.50 & 0.10 & 0 & 1 \\
\hline 2015 & 1 & 1.1 & 89 & 98.9 & 0.50 & 0.10 & 0 & 1 \\
\hline 2016 & 1 & 1.1 & 89 & 98.9 & 0.50 & 0.10 & 0 & 1 \\
\hline 2017 & 1 & 1.1 & 89 & 98.9 & 0.50 & 0.10 & 0 & 1 \\
\hline
\end{tabular}

Note: Each year's sample contains 90 companies.

Table 12. Overview of contact information.

\begin{tabular}{ccccccccc}
\hline Years & \multicolumn{2}{c}{ Present } & \multicolumn{2}{c}{ Absent } & Mean & $\begin{array}{c}\text { Std. } \\
\text { Dev. }\end{array}$ & Mini & Maxi. \\
\hline & $N$ & $\%$ & $N$ & $\%$ & & & & \\
\hline 2012 & 69 & 76.7 & 21 & 23.3 & 0.62 & 0.21 & 0.5 & 1 \\
2013 & 70 & 77.8 & 20 & 22.2 & 0.61 & 0.21 & 0.5 & 1 \\
2014 & 71 & 78.9 & 19 & 21.1 & 0.61 & 0.21 & 0.5 & 1 \\
2015 & 71 & 78.9 & 19 & 21.1 & 0.61 & 0.21 & 0.5 & 1 \\
2016 & 71 & 78.9 & 19 & 21.1 & 0.61 & 0.21 & 0.5 & 1 \\
2017 & 71 & 78.9 & 19 & 21.1 & 0.61 & 0.21 & 0.5 & 1 \\
\hline Note: Sample size is 90 companies per year.
\end{tabular}


A large number of sampled companies disclosed assurance statements in their annual reports (2015: 89 companies, 98.9\%, 2014 and 2013: 89 companies, 98.9\%; 2012: 86 companies, $95.6 \%)$ and only one company $(1.1 \%)$ did not disclose any assurance statement from 2012 to 2017.

Table 12 shows that the company contact information is provided in the CSR report. The report reader can verify whether this information is correct where a contact person's name, telephone number, or email address is provided. Many sampled companies provide contact information in their CSR reports (71 companies, 78.9\%) so that stakeholders can get information; a small number of companies (19 companies, 21.1\%) disclosed no contact information in 2017. Similar to 2017, contact information is present in CSR reports of a large number of companies (2016: 71 companies, 78.9\%, 2015: 71 companies, 78.9\%, 2014: 71 companies, 78.9\%; 2013: 70 companies, 77.8\%; 2012: 69 companies, 76.7\%), whereas contact information is absent in a small number of companies (2016: 19 companies, 21.1\%, 2015: 19 companies, 21.1\%, 2014: 19 companies, 21.1\%; 2013: 20 companies, 22.2\%; 2012: 21 companies, $23.3 \%$ ).

\subsection{Overall Quality of CSR Disclosure in Pakistan}

To assess the overall or aggregated quality of CSR disclosure, this study first computed standardized scores for each of the quality principles separately. The standardized score of each quality principle was calculated by adding the scores and then divided by the total number of indicators. The overall (aggregated) disclosure quality score was a function of six measures (indicators) representing the quality principles: balance, comparability, accuracy, timeliness, and reliability. The researcher equally weighted the sub-scores that composed the aggregated score because there was no reason to prioritize one attribute over the others, which was consistent with existing studies on disclosure quality.

An overall score of $50 \%$ was recorded in our analysis for the quality of CSR disclosure in Pakistan as per the quality principles of the Global Reporting Initiative. Among the six quality principles, regularity and clarity received the highest scores of $73 \%$ and $72 \%$, respectively, while reliability received a $67 \%$ score in our analysis. In this regard, these three quality principles received above-average scores. The quality principles which were lagging in Pakistan and received below-average scores include balance, accuracy, and comparability. Only $38 \%$ of the CSR information can be declared balanced, while $21 \%$ of CSR information fulfil comparability criteria. The accuracy principle was least followed among Pakistani firms, as only $20 \%$ of CSR disclosures provide enough accurate information to judge performance. Descriptive stats for each element of the quality principles and the overall quality score are provided in Table 13 below.

Table 13. Descriptive statistics of quality of CSR disclosure measure in Pakistani listed companies.

\begin{tabular}{|c|c|c|c|c|c|c|}
\hline $\begin{array}{c}\text { Qualitative } \\
\text { Characteristics }\end{array}$ & Items & Mean & Std. Dev. & Minimum & Median & Maximum \\
\hline \multicolumn{7}{|l|}{ Balance } \\
\hline B1 & $\begin{array}{l}\text { To what extent does the company in the discussion of CSR in } \\
\text { the annual report, highlight the positive events as well as the } \\
\text { negative events? }\end{array}$ & 0.53 & 0.18 & 0.20 & 0.60 & 1 \\
\hline \multirow[t]{2}{*}{ B2 } & $\begin{array}{l}\text { To what extent does the company in the discussion of CSR in } \\
\text { annual report, allow users to see positive and negative trends in } \\
\text { performance on a year to year basis? }\end{array}$ & 0.22 & 0.09 & 0.20 & 0.20 & 0.60 \\
\hline & Balance total score & 0.38 & 0.11 & 0.20 & 0.40 & 0.8 \\
\hline \multicolumn{7}{|l|}{ Comparability } \\
\hline $\mathrm{C} 1$ & $\begin{array}{l}\text { To what extent is the information of CSR in the annual report } \\
\text { comparable to information provided by other organization? }\end{array}$ & 0.20 & 1.33 & 0.20 & 0.20 & 0.20 \\
\hline \multirow[t]{2}{*}{$\mathrm{C} 2$} & $\begin{array}{l}\text { To what extent report compared CSR information on a } \\
\text { year-to-year basis }\end{array}$ & 0.22 & 0.10 & 0.20 & 0.20 & 1 \\
\hline & Comparability total score & 0.21 & 0.05 & 0.20 & 0.20 & 0.6 \\
\hline
\end{tabular}


Table 13. Cont.

\begin{tabular}{|c|c|c|c|c|c|c|}
\hline $\begin{array}{c}\text { Qualitative } \\
\text { Characteristics }\end{array}$ & Items & Mean & Std. Dev. & Minimum & Median & Maximum \\
\hline \multicolumn{7}{|l|}{ Accuracy } \\
\hline A1 & $\begin{array}{l}\text { To what extent CSR activities are accurately disclosed for } \\
\text { stakeholders to assess the organization's performance }\end{array}$ & 0.24 & 0.20 & 0 & 0.20 & 1 \\
\hline \multicolumn{7}{|l|}{ Timeliness } \\
\hline $\mathrm{T} 1$ & $\begin{array}{l}\text { Do information in the report clearly indicates the time period } \\
\text { and updated accordingly? (for regularity) }\end{array}$ & 0.93 & 0.17 & 0.5 & 1 & 1 \\
\hline \multirow[t]{2}{*}{$\mathrm{T} 2$} & There is a consistent reporting schedule.(for proximity) & 0.53 & 0.13 & 0.5 & 0.50 & 1 \\
\hline & Timeliness total score & 0.73 & 0.08 & 0.5 & 0.75 & 1 \\
\hline \multicolumn{7}{|l|}{ Clarity } \\
\hline $\mathrm{Cl}$ & $\begin{array}{l}\text { To what extent CSR information is understandable to } \\
\text { various stakeholders. }\end{array}$ & 0.72 & 0.26 & 0.5 & 0 & 1 \\
\hline \multicolumn{7}{|l|}{ Reliability } \\
\hline R1 & $\begin{array}{l}\text { There is an assurance statement which includes the assurance of } \\
\text { reporting data. }\end{array}$ & 0.74 & 0.26 & 0 & 0.5 & 1 \\
\hline \multirow[t]{2}{*}{ R2 } & Company contact Information is provided in the CSR report & 0.61 & 0.21 & 0.5 & 0.5 & 1 \\
\hline & Reliability total score & 0.67 & 0.16 & 0.25 & 0.75 & 1 \\
\hline Total QULD & & 0.49 & 0.06 & 0.32 & 0.48 & 0.67 \\
\hline
\end{tabular}

Note: Sample size is 540 companies.

\section{Discussion and Conclusions}

The significant contribution of GRI is in the field of sustainability reporting, where it can reduce uncertainty and increase legitimacy [50]. Moreover, GRI qualitative characteristics were meant to answer new legitimacy problems [50] and to develop a sustainable business model (materiality matrix) [51]. GRI guidelines and their qualitative characteristics are not only applied to large business entities, but are equally applied to SMEs [52].

This study examines the quality of CSR information disclosed by the Pakistan Stock Exchange-listed companies from 2012-2017. The results show that in total, from the year 2012 to 2017, 50\% of sampled companies disclosed CSR information by following qualitative characteristics (GRI principles). Since the introduction of the CSR order in 2009 by the Security and Exchange Commission of Pakistan (SECP), CSR issues among listed companies at PSE have increased. Studies have adopted some practices.

The quality of the CSR disclosure result revealed that the sampled companies, in the six years 2012-2017, gave more attention to providing timely information. This study also indicates that most companies disclose financial information regularly with a clear indication of the specific period and update accordingly. Still, reporting has not improved nor updated the timeliness of CSR information. This result is consistent with Rosenström and Lyytimäki [48]. Rosenström and Lyytimäki [48] found in their study that environmental indicators did not significantly affect the timeliness of CSR information because a CSR report is concise, and publishing times can be shortened considerably, thereby ensuring the timeliness of the information. The results of this study are consistent with Chakroun and Hussainey [17], who found that timeliness was the highest qualitative characteristic for the sampled companies. In addition to other attributes, such as disclosure quality, the clarity of CSR information is an important characteristic. This study found that $72 \%$ of the companies disclose clear information with accessible language and easy to find. This result is consistent with Hervieux, McKee [53], who found that companies usually disclose clear information by avoiding the technical terms. Still, clarity is uncertain when access to information is difficult. Moreover, a lack of clear CSR information is perceived with normative connotations, and companies have no clear understanding of the disclosers of social issues as corporate or business matters [54]. 
Reliable information in CSR disclosure is the third most crucial characteristic found in sampled companies. To improve the quality of CSR disclosure, the sampled companies have independent assurances that verify the reliability of CSR disclosure. The assurance process promotes legitimate and normatively appropriate reporting practice [55]. This study found that more than $80 \%$ of the sampled companies disclose assurance statements with the perspective of companies financial performance, whereas financial audit on the development of sustainability assurance practice is missing.

This study is consistent with Boiral [22,32], who found that the assurance process makes sustainability disclosure more reliable and transparent. At the same time, Brendan [56] found that vague guidance on sustainability assurance practice is the leading cause that companies do not provide detailed information for sustainability audits.

This research also found that more than $70 \%$ of the sampled companies disclose contact information so that the readers or stakeholders can verify CSR-related information. In addition to this, the sampled companies lack balanced information regarding favorable/positive and unfavorable/negative events in annual reports. Most companies give attention to disclosing favorable or favorable circumstances to improve company reputation and legitimacy [57]. Imbalance disclosure is more pronounced in disclosing CSR information separately, and disclosure on a year-to-year basis can endanger corporate legitimacy. This result clearly shows that sampled companies promote or enhance the organizations by disclosing positive events in CSR reports and hide negative impacts and aspects. This result is consistent with $[53,57,58]$. According to Criado-Jiménez, FernándezChulián [58], previous research has disclosed consistent bias towards presenting the best possible image of the organization. By following the balance principle of GRI 2018, the firms will find it more difficult to terminate substantive aspects of this norm (normative pressure), and bias is likely. Therefore, positive disclosure will increase relatively more than adverse disclosure. Companies disclose non-financial information in response to an inquiry $[59,60]$. The researcher also believes that disclosure of CSR information can help organizations avoid coercive pressure and generate impressions for sustainable performance [61,62]. Another component to evaluate report quality is by providing accurate information in the annual report. The findings of this study reveal that very little information is provided to performance indicators for accurate information. At the same time, most companies have disclosed aims, actions, and narratives disclosure of CSR information [63]. A similar study was conducted by Neu, Warsame [64] and Waris [63], who found that companies prefer to disclose qualitative information to manage public impressions (and reinforce their legitimacy) and meet the expectation of influential stakeholders (coercive pressure) rather than to express their accountability.

In addition, the stakeholders ask companies to disclose complete and truthful accounts of actions in order to legitimize reporting practices [65]. For example García-Sánchez, Raimo [66] focused on legitimacy theory in the disclosure field, and showed that inclusion of truthful information help a company defend its legitimacy even in the era of the COVID19 pandemic where organization has to become a good corporate citizen and fulfill the expectation of the public in relation to the dissemination of true information.

While the sampled companies discussed ethical statements and business activities in their annual reports, for example, compliance with environmental law [67], honest dealing with employees, fair competition [68], and anti-trust laws, this research found that ethical behavior took on a symbolic gesture, and did not find any specific metrics that the sampled companies used to assess their performance. Therefore, the annual report of sampled companies cannot help stakeholders judge their accuracy (GRI P7 Accuracy). The GRI is said to be most effective at empowering stakeholders when the information presented is valuable, accessible, comprehensible, and comparable [69] and gain legitimacy by communicating environmental disclosures to stakeholders [53]. This research found that the sampled companies did not disclose even a single paragraph comparing CSR information with other organizations (75 companies, 21\%) from 2012 to 2015. Ref. [53] found consistent results, where variations in the content of reports make comparability difficult 
between the organizations. This low level of comparability in discussing environmental issues (pragmatic legitimacy) can be due to stakeholders' lower level of interest in disclosing such a type of comparative information. In general, companies in developing countries are less alarmed by revealing relative information regarding environmental issues. According to Dingwerth and Eichinger [69], the company's reports become useful for stakeholders if the disclosure led to a more remarkable ability to compare CSR information across years and across companies.

The result shows that the companies listed on the Pakistan stock exchange have not disclosed balanced CSR information in annual reports. Companies are more concerned about disclosing positive or favorable events to improve company reputation and legitimacy [57] while hiding negative impact and aspects. Similar results are found in the studies of Hervieux, McKee [53], Hahn and Lülfs [57], Criado-Jiménez, Fernández-Chulián [58]. Comparable and comprehensive information effectively empowers stakeholders [69] and improves legitimacy [53]. This research found that sampled companies have not disclosed even a single paragraph for comparing CSR information with other organizations (75 companies, 21\%) from 2012 to 2015. A similar study was conducted by Hervieux, McKee [53], who discovered that the variations in the content of reports make a comparison of information difficult between organizations. Moreover, stakeholders in developing countries are not very concerned with comparing information disclosed in CSR reports, compared to stakeholders than in developed countries.

According to Dingwerth and Eichinger [69], companies' reports become useful for stakeholders if the disclosure resulted in a greater ability to compare CSR information across years and across companies.

In addition, sampled companies do not help in providing accurate information to their stakeholders. At the same time, the researcher found some ethical statements and social practices in their annual reports, such as honesty in dealing and compliance with anti-trust law, employment, and environmental law. This research has not found any metric for the presentation of accurate information. The results also reveal that most companies listed on the Pakistan Stock Exchange disclosed financial information regularly, clearly indicating the specific period and updating accordingly. Still, reporting has not improved or updated the timeliness of CSR information. Consistent results were found by Rosenström and Lyytimäki [48]. Rosenström and Lyytimäki [48] found in their study that environmental indicators did not significantly affect the timeliness of CSR information, because CSR reports are concise and publishing times can be shortened considerably, thereby ensuring the timeliness of the information. Chakroun and Hussainey [17] showed that timeliness has the highest qualitative characteristic that companies follow in disclosing CSR information. Clarity is uncertain when access to information is complex and when organizations consider the social issue a business issue [54]. A total of $72 \%$ of the companies disclose clear information in accessible language that is easy to find. Hervieux, McKee [53] found that usually companies usually disclose clear information by avoiding technical terms. The above results show that the sampled companies listed in the Pakistan Stock Exchange have paid less attention to provide qualitative information in CSR disclosure [1]

This paper assessed the quality of CSR disclosure in annual reports of firms listed at the Pakistan Stock Exchange. Our empirical results found that the overall quality of the information in annual reports is quite limited. Even reporting practices lack a strategy regarding qualitative information.

The limitation of this study is we analyzed only annual reports during a the specific period and ignored other periods and other sources of information, like websites, triple bottom reports, and CSR reports.

This study can be helpful for future studies in different ways. From the methodology perspective, further research can be done by increasing the number of companies and the period for analysis. A case study methodology and an interview from an organization's CEO can give a deeper insight into evaluating the qualitative aspects of CSR reports. Moreover, this research can be extended by taking internal determinants for quality of 
information disclosed in CSR reports -related to CSR governance and external determinantsrelated to institutions field factors. Similarly, the consequences of quality of information in CSR disclosure could be another aspect to examine.

Finally, the overall quality and quantity of CSR disclosure are two independent dimensions; it requires more investigation to determine whether an assessment of comprehensive CSR disclosure has to be taken into consideration where the quality of information and quantity of disclosure have some correlation. In addition, this research can be helpful in performing materiality analysis in the process of reporting nonfinancial performance. By doing this, companies can prioritize sustainability issues and understand stakeholders' interest.

This research focused on listed companies of the Pakistan Stock exchange. Future studies should investigate on the behavior of small and medium companies that adopt a mimetic behavior related to the actions of listed companies.

Author Contributions: Writing—original draft preparation, H.I.; data and analysis, M.A.S.; methodology, S.Z.; write up: M.S.T.; data collection, R.A.A.; All authors have read and agreed to the published version of the manuscript.

Funding: The research was supported by Charles Darwin University through its "Open Access Support for Increased Citations" (OASIC) initiative.

Institutional Review Board Statement: The study was conducted according to the guidelines and protocols of National University of Modern Languages and approved by the Research Ethics Board.

Informed Consent Statement: Informed consent was obtained from all subjects involved in the study.

Data Availability Statement: Data are not publicly available for this article.

Conflicts of Interest: The authors declare no conflict of interest.

Appendix A

Table A1. Description of CSR Disclosure Quality Index.

\begin{tabular}{|c|c|c|c|}
\hline Indicators & Questions & Operationalization & Literature \\
\hline \multicolumn{4}{|l|}{ Balance } \\
\hline B1 & $\begin{array}{l}\text { To what extent does the } \\
\text { company in the discussion of } \\
\text { CSR in the annual report, } \\
\text { highlight the positive events } \\
\text { as well as the } \\
\text { negative events? }\end{array}$ & $\begin{array}{l}1=\text { No positive and negative events are mentioned } \\
2=\text { Negative events only mentioned in footnotes } \\
3=\text { Emphasize on positive events } \\
4=\text { Balance positive/negative events of CSR } \\
5=\text { Impact of positive/negative events of CSR is } \\
\text { also explained }\end{array}$ & $\begin{array}{l}\text { For example, }[22,29] \\
\text { and GRI }(2017)\end{array}$ \\
\hline B2 & $\begin{array}{l}\text { To what extent does the } \\
\text { company in the discussion of } \\
\text { CSR in annual report, allow } \\
\text { users to see positive and } \\
\text { negative trends in } \\
\text { performance on a year to } \\
\text { year basis? }\end{array}$ & $\begin{array}{l}1=\text { No positive and negative performance are mentioned } \\
\text { separately and year to year basis } \\
2=\text { negative performance only mentioned separately and } \\
\text { year to year basis } \\
3 \text { = Positive performance mentioned separately and year to } \\
\text { year basis } \\
4=\text { Balance positive/negative performance of CSR } \\
\text { mentioned separately and year to year basis } \\
5=\text { Impact of positive/negative performance of CSR is also } \\
\text { explained on year to year basis }\end{array}$ & [22,29] and GRI (2017) \\
\hline
\end{tabular}


Table A1. Cont.

\begin{tabular}{|c|c|c|c|}
\hline Indicators & Questions & Operationalization & Literature \\
\hline \multicolumn{4}{|c|}{ Comparability } \\
\hline $\mathrm{C} 1$ & $\begin{array}{l}\text { To what extent is the } \\
\text { information of CSR in the } \\
\text { annual report comparable to } \\
\text { information provided by } \\
\text { other organization? }\end{array}$ & $\begin{array}{l}1=\text { No comparability (no paragraph) } 2=\text { Limited } \\
\text { comparability (one paragraph) } 3=\text { Moderate comparability } \\
\text { (two paragraph) } 4=\text { Very much comparability (two } \\
\text { paragraphs with numbering) } 5=\text { Very extensive } \\
\text { comparability (more than two paragraph) }\end{array}$ & $\begin{array}{l}\text { For example, }[2,17,27] \text {, } \\
\text { GRI }(2017)\end{array}$ \\
\hline $\mathrm{C} 2$ & $\begin{array}{l}\text { To what extent report } \\
\text { compared CSR information } \\
\text { on a year-to-year basis }\end{array}$ & $\begin{array}{l}1=\text { No comparability (no prior year) } \\
2=\text { Limited comparability (one year) } \\
3=\text { Moderate comparability (two years) } \\
4=\text { Very much comparability (three years) } \\
5=\text { Very extensive comparability (more than } 3 \text { years) }\end{array}$ & $\begin{array}{l}\text { For example, }[2,17,27] \text {, } \\
\text { GRI }(2017)\end{array}$ \\
\hline
\end{tabular}

Accuracy

To what extent CSR activities are accurately disclosed for stakeholders to assess the organization's performance
$0=$ No information disclosed regarding CSR

$1=$ Only qualitative information is disclosed.

$2=$ Qualitative information is disclosed with same quantitative information.

$3=$ More quantitative information is disclosed along with $\quad[2,29,30]$, GRI (2017). qualitative information.

4 = Data measurement technique and basic for calculation are adequately describe.

$5=$ Estimation and underlying assumptions are disclosed.

\begin{tabular}{|c|c|c|c|c|}
\hline \multicolumn{5}{|c|}{ Timeliness } \\
\hline $\mathrm{T} 1$ & $\begin{array}{l}\text { Do information in the report } \\
\text { clearly indicates the time } \\
\text { period and updated } \\
\text { accordingly? (for regularity) }\end{array}$ & \multicolumn{2}{|l|}{$\begin{array}{l}1=\text { No time specified } \\
2=\text { Time specified }\end{array}$} & {$[1,29,30,48]$, GRI $(2017)$} \\
\hline $\mathrm{T} 2$ & $\begin{array}{l}\text { There is a consistent } \\
\text { reporting schedule. } \\
\text { (for proximity) }\end{array}$ & \multicolumn{2}{|l|}{$\begin{array}{l}1=\text { yes } \\
2=\text { No }\end{array}$} & {$[30,48,70]$, GRI (2017) } \\
\hline \multicolumn{5}{|c|}{ Clarity } \\
\hline & & \multicolumn{2}{|l|}{ Understandability Index } & \\
\hline $\mathrm{Cl}$ & $\begin{array}{l}\text { To what extent CSR } \\
\text { information is } \\
\text { understandable to } \\
\text { various stakeholders. }\end{array}$ & $\begin{array}{ll}\text { 1. } & \text { Table of contents } \\
\text { 2. } & \text { Other } \\
\text { 3. } & \text { Tables } \\
\text { 4. } & \text { Graphs } \\
\text { 5. } & \text { Maps } \\
\text { 6. } & \text { List of abbreviation } \\
\text { 7. } & \text { Pictures } \\
\text { 8. } & \text { Multiple languages }\end{array}$ & $\begin{array}{l}\text { Present } \\
\text { Absent }\end{array}$ & $\begin{array}{l}\text { For example, }[17,31] \\
{[17,31,71], \text { GRI }(2017)}\end{array}$ \\
\hline \multicolumn{5}{|c|}{ Reliability } \\
\hline R1 & $\begin{array}{l}\text { There is an assurance } \\
\text { statement which includes the } \\
\text { assurance of reporting data. }\end{array}$ & \multicolumn{2}{|c|}{$\begin{array}{l}1=\text { No external assurance } \\
2=\text { External assurance (can be name of assurance provider } \\
\text { like accountant, engineering firm, small consultancy firm) }\end{array}$} & {$[11,30,70]$, GRI $(2017)$} \\
\hline R2 & $\begin{array}{l}\text { Company contact } \\
\text { Information is provided in } \\
\text { the CSR report }\end{array}$ & \multicolumn{2}{|l|}{$\begin{array}{l}1=\text { Present } \\
2=\text { Absent }\end{array}$} & {$[30,70]$, GRI $(2017)$} \\
\hline
\end{tabular}




\section{References}

1. Beretta, S.; Bozzolan, S. Quality versus quantity: The case of forward-looking disclosure. J. Account. Audit. Financ. 2008, 23, 333-376. [CrossRef]

2. Michelon, G.; Pilonato, S.; Ricceri, F. CSR reporting practices and the quality of disclosure: An empirical analysis. Crit. Perspect. Account. 2015, 33, 59-78. [CrossRef]

3. Habek, P.; Wolniak, R. Factors influencing the development of CSR reporting practices: Experts' versus preparers' points of view. Eng. Econ. 2015, 26, 560-570. [CrossRef]

4. Archel, P.; Husillos, J.; Spence, C. The institutionalisation of unaccountability: Loading the dice of Corporate Social Responsibility discourse. Account. Organ. Soc. 2011, 36, 327-343. [CrossRef]

5. Gray, R. Is accounting for sustainability actually accounting for sustainability ... and how would we know? An exploration of narratives of organisations and the planet. Account. Organ. Soc. 2010, 35, 47-62. [CrossRef]

6. Martin, P.R.; Moser, D.V. Managers' green investment disclosures and investors' reaction. J. Account. Econ. 2016, 61, 239-254. [CrossRef]

7. Deegan, C.; Gordon, B. A study of the environmental disclosure practices of Australian corporations. Account. Bus. Res. 1996, 26, 187-199. [CrossRef]

8. Pizzi, S.; Venturelli, A.; Caputo, F. The "comply-or-explain" principle in directive 95/2014/EU. A rhetorical analysis of Italian PIEs. Sustain. Account. Manag. Policy J. 2020, 12, 30-50. [CrossRef]

9. Abd-Mutalib, H.; Jamil, C.Z.M.; Wan-Hussin, W.N. The Availability, Extent and Quality of Sustainability Reporting by Malaysian Listed Firms: Subsequent to Mandatory Disclosure. Asian J. Financ. Account. 2014, 6, 239-260. [CrossRef]

10. Everaert, P.; Bouten, L.; Van Liedekerke, L.; De Moor, L.; Christiaens, J. Voluntary Disclosure of Corporate Social Responsibility by Belgian Listed Firms: A Content Analysis of Annual Reports; Citeseer: Pennsylvania, PA, USA, 2007.

11. Hammond, K.; Miles, S. Assessing Quality Assessment of Corporate Social Reporting: UK Perspectives. In Accounting Forum; Elsevier: Amsterdam, The Netherlands, 2004.

12. Aras, G.; Tezcan, N.; Kutlu Furtuna, O. Multidimensional comprehensive corporate sustainability performance evaluation model: Evidence from an emerging market banking sector. J. Clean. Prod. 2018, 185, 600-609. [CrossRef]

13. Abdillah, A.A.; Husin, N.M. A Longitudinal Examination Corporate Social Responsibility Reporting Practices among Top Banks in Malaysia. Procedia Econ. Financ. 2016, 35, 10-16. [CrossRef]

14. Ortas, E.; Gallego-Alvarez, I.; Etxeberria, I.Á. Financial Factors Influencing the Quality of Corporate Social Responsibility and Environmental Management Disclosure: A Quantile Regression Approach. Corp. Soc. Responsib. Environ. Manag. 2015, 22, 362-380. [CrossRef]

15. Ali, W.; Frynas, J.G.; Mahmood, Z. Determinants of Corporate Social Responsibility (CSR) Disclosure in Developed and Developing Countries: A Literature Review. Corp. Soc. Responsib. Environ. Manag. 2017, 24, 273-294. [CrossRef]

16. Anis, R.; Fraser, I.; Hussainey, K. A New Measure for Disclosure Quality; working paper; Stirling University: Scotland, UK, 2012.

17. Chakroun, R.; Hussainey, K. Disclosure quality in Tunisian annual reports. Corp. Ownersh. Control 2014, 11, 58-80. [CrossRef]

18. Mahmood, Z.; Kouser, R.; Ali, W.; Ahmad, Z.; Salman, T. Does Corporate Governance Affect Sustainability Disclosure? A Mixed Methods Study. Sustainability 2018, 10, 207. [CrossRef]

19. Fifka, M.S. Corporate Responsibility Reporting and its Determinants in Comparative Perspective-A Review of the Empirical Literature and a Meta-analysis. Bus. Strategy Environ. 2013, 22, 1-35. [CrossRef]

20. Dobers, P.; Halme, M. Corporate social responsibility and developing countries. Corp. Soc. Responsib. Environ. Manag. 2009, 16, 237-249. [CrossRef]

21. Brown, H.S.; de Jong, M.; Lessidrenska, T. The rise of the Global Reporting Initiative: A case of institutional entrepreneurship. Environ. Politics 2009, 18, 182-200. [CrossRef]

22. Boiral, O. Sustainability reports as simulacra? A counter-account of A and A+ GRI reports. Account. Audit. Account. J. 2013, 26, 1036-1071. [CrossRef]

23. Odriozola, M.D.; Baraibar-Diez, E. Is Corporate Reputation Associated with Quality of CSR Reporting? Evidence from Spain. Corp. Soc. Responsib. Environ. Manag. 2017, 24, 121-132. [CrossRef]

24. Beest, F.; Braam, G.; Boelens, S. Quality of Financial Reporting: Measuring Qualitative Characteristics. Available online: https:/ / repository.ubn.ru.nl/bitstream/handle/2066/74896/74896.pdf (accessed on 8 October 2021).

25. Beattie, V.; McInnes, B.; Fearnley, S. A methodology for analysing and evaluating narratives in annual reports: A comprehensive descriptive profile and metrics for disclosure quality attributes. In Accounting Forum; Elsevier: Amsterdam, The Netherlands, 2004.

26. Botosan, C.A. Discussion of a framework for the analysis of firm risk communication. Int. J. Account. 2004, 39, 289-295. [CrossRef]

27. Alotaibi, K.O.; Hussainey, K. Determinants of CSR disclosure quantity and quality: Evidence from non-financial listed firms in Saudi Arabia. Int. J. Discl. Gov. 2016, 13, 364-393. [CrossRef]

28. Beretta, S.; Bozzolan, S. A framework for the analysis of firm risk communication. Int. J. Account. 2004, 39, 265-288. [CrossRef]

29. Diouf, D.; Boiral, O. The quality of sustainability reports and impression management: A stakeholder perspective. Account. Audit. Account. J. 2017, 30, 643-667. [CrossRef]

30. Comyns, B. Climate Change Reporting and Multinational Companies: Insights from Institutional Theory and International Business. In Accounting Forum; Elsevier: Amsterdam, The Netherlands, 2017. 
31. Habek, P.; Wolniak, R. Assessing the quality of corporate social responsibility reports: The case of reporting practices in selected European Union member states. Qual. Quant. 2016, 50, 399-420. [CrossRef] [PubMed]

32. Leitoniene, S.; Sapkauskiene, A. Quality of Corporate Social Responsibility Information. Procedia-Soc. Behav. Sci. 2015, 213, 334-339. [CrossRef]

33. Brammer, S.; Pavelin, S. Factors influencing the quality of corporate environmental disclosure. Bus. Strategy Environ. 2008, 17, 120-136. [CrossRef]

34. Raar, J. Environmental initiatives: Towards triple-bottom line reporting. Corp. Commun. Int. J. 2002, 7, 169-183. [CrossRef]

35. Masulis, R.W.; Wang, C.; Xie, F. Globalizing the boardroom-The effects of foreign directors on corporate governance and firm performance. J. Account. Econ. 2012, 53, 527-554. [CrossRef]

36. Morhardt, J.E. Corporate social responsibility and sustainability reporting on the internet. Bus. Strategy Environ. 2010, 19, 436-452. [CrossRef]

37. Prado-Lorenzo, J.M.; Gallego-Alvarez, I.; Garcia-Sanchez, I.M. Stakeholder engagement and corporate social responsibility reporting: The ownership structure effect. Corp. Soc. Responsib. Environ. Manag. 2009, 16, 94-107. [CrossRef]

38. Yuan, J.; Wang, Y.; Hu, W.; Bruno, A. The reliability and validity of a novel Chinese version simplified modified Rankin scale questionnaire (2011). BMC Neurol. 2020, 20, 127. [CrossRef] [PubMed]

39. Cormier, D.; Magnan, M.; Van Velthoven, B. Environmental disclosure quality in large German companies: Economic incentives, public pressures or institutional conditions? Eur. Account. Rev. 2005, 14, 3-39. [CrossRef]

40. van Staden, C.J.; Hooks, J. A comprehensive comparison of corporate environmental reporting and responsiveness. Br. Account. Rev. 2007, 39, 197-210. [CrossRef]

41. Ane, P. An Assessment of the Quality of Environmental Information Disclosure of Corporation in China. Syst. Eng. Procedia 2012, 5 (Suppl. SC), 420-426. [CrossRef]

42. Ismail, H.; Mahmood, Z. CSR Profile of Developing Nations: A Content Analysis of CSR Reports of Listed Companies in Pakistan. Pak. J. Soc. Sci. (PJSS) 2019, 39, 1681-1698.

43. Cho Michelon, G.; Patten, D.M. Impression management in sustainability reports: An empirical investigation of the use of graphs. Account. Public Interest 2012, 12, 16-37.

44. Adams, C.A.; Frost, G.R. Accessibility and functionality of the corporate web site: Implications for sustainability reporting. Bus. Strategy Environ. 2006, 15, 275-287. [CrossRef]

45. Langer, M. Comparability of sustainability reports. A comparative content analysis of Austrian sustainability reports. In Sustainability Accounting and Reporting; Springer: Berlin/Heidelberg, Germany, 2006; pp. 581-602.

46. Gray, R.; Javad, M.; Power, D.M.; Sinclair, C.D. Social and Environmental Disclosure and Corporate Characteristics: A Research Note and Extension. J. Bus. Financ. Account. 2001, 28, 327-356. [CrossRef]

47. Manetti, G.; Becatti, L. Assurance services for sustainability reports: Standards and empirical evidence. J. Bus. Ethics 2009, 87, 289-298. [CrossRef]

48. Rosenström, U.; Lyytimäki, J. The role of indicators in improving timeliness of international environmental reports. Eur. Environ. 2006, 16, 32-44. [CrossRef]

49. Cho Michelon, G.; Patten, D.M.; Roberts, R.W. CSR disclosure: The more things change ... ? Account. Audit. Account. J. 2015, 28, 14-35.

50. Brown, H.S.; de Jong, M.; Levy, D.L. Building institutions based on information disclosure: Lessons from GRI's sustainability reporting. J. Clean. Prod. 2009, 17, 571-580. [CrossRef]

51. Geldres-Weiss, V.V.; Gambetta, N.; Massa, N.P.; Geldres-Weiss, S.L. Materiality Matrix Use in Aligning and Determining a Firm's Sustainable Business Model Archetype and Triple Bottom Line Impact on Stakeholders. Sustainability 2021, 13, 1065. [CrossRef]

52. Krawczyk, P. Non-Financial Reporting-Standardization Options for SME Sector. J. Risk Financ. Manag. 2021, 14, 417. [CrossRef]

53. Hervieux, C.; McKee, M.; Driscoll, C. Room for improvement: Using GRI principles to explore potential for advancing PRME SIP reporting. Int. J. Manag. Educ. 2017, 15 Pt B, 219-237. [CrossRef]

54. Rizk, R.; Dixon, R.; Woodhead, A. Corporate social and environmental reporting: A survey of disclosure practices in Egypt. Soc. Responsib. J. 2008, 4, 306-323. [CrossRef]

55. Boiral, O.; Henri, J.-F. Is sustainability performance comparable? A study of GRI reports of mining organizations. Bus. Soc. 2017, 56, 283-317. [CrossRef]

56. Brendan, O.D. The Case of Sustainability Assurance: Constructing a New Assurance Service. Contemp. Account. Res. 2011, 28, 1230-1266. [CrossRef]

57. Hahn, R.; Lülfs, R. Legitimizing negative aspects in GRI-oriented sustainability reporting: A qualitative analysis of corporate disclosure strategies. J. Bus. Ethics 2014, 123, 401-420. [CrossRef]

58. Criado-Jiménez, I.; Fernández-Chulián, M.; Larrinaga-González, C.; Husillos-Carqués, F.J. Compliance with mandatory environmental reporting in financial statements: The case of Spain (2001-2003). J. Bus. Ethics 2008, 79, 245-262. [CrossRef]

59. Haniffa, R.M.; Cooke, T.E. The impact of culture and governance on corporate social reporting. J. Account. Public Policy 2005, 24, 391-430. [CrossRef]

60. Fortanier, F.; Kolk, A.; Pinkse, J. Harmonization in CSR Reporting: MNEs and Global CSR Standards. MIR Manag. Int. Rev. 2011, 51, 665-696. [CrossRef] 
61. Deegan, C. Introduction: The legitimising effect of social and environmental disclosures-A theoretical foundation. Account. Audit. Account. J. 2002, 15, 282-311. [CrossRef]

62. Brown, N.; Deegan, C. The public disclosure of environmental performance information-A dual test of media agenda setting theory and legitimacy theory. Account. Bus. Res. 1998, 29, 21-41. [CrossRef]

63. Waris, A. Corporate Social Responsibility Disclosure (CSRD): A Case Study of Pakistan; Middlesex University: London, UK, 2014.

64. Neu, D.; Warsame, H.; Pedwell, K. Managing public impressions: Environmental disclosures in annual reports. Account. Organ. Soc. 1998, 23, 265-282. [CrossRef]

65. Adams, C.A.; Evans, R. Accountability, completeness, credibility and the audit expectations gap. J. Corp. Citizsh. 2004, 14, 97-115. [CrossRef]

66. García-Sánchez, I.-M.; Raimo, N.; Marrone, A.; Vitolla, F. How does integrated reporting change in light of COVID-19? A Revisiting of the content of the integrated reports. Sustainability 2020, 12, 7605. [CrossRef]

67. Saleem, M.A.; Ismail, H.; Ali, R.A. Actions speak louder than words: Investigating the interplay 2 between descriptive and injunctive norms to promote alterna-3 tive fuel vehicles 4 . Sustainability 2021, 13, 9662. [CrossRef]

68. Saleem, M.A.; Eagle, L.; Low, D. Determinants of eco-socially conscious consumer behavior toward alternative fuel vehicles. J. Consum. Mark. 2021, 38, 211-228. [CrossRef]

69. Dingwerth, K.; Eichinger, M. Tamed transparency: How information disclosure under the global reporting initiative fails to empower. Glob. Environ. Politics 2010, 10, 74-96. [CrossRef]

70. Breeda, C.; Frank, F. Greenhouse gas reporting quality in the oil and gas industry: A longitudinal study using the typology of "search", "experience" and "credence" information. Account. Audit. Account. J. 2015, 28, 403-433. [CrossRef]

71. Jonas, G.J.; Blanchet, J. Assessing quality of financial reporting. Account. Horiz. 2000, 14, 353-363. [CrossRef] 